\title{
PROFIL BERPIKIR KRITIS PESERTA DIDIK DITINJAU DARI GAYA KOGNITIF DALAM MEMECAHKAN MASALAH MATEMATIKA
}

\author{
Nathasa Pramudita Irianti*1 ${ }^{1}$, Rio Febrianto Arifendi ${ }^{2}$, Elita Mega Selvia \\ Wijaya $^{3}$ \\ 1,2, 3 Universitas Tribhuwana Tunggadewi \\ nathasa1990@gmail.com*¹, rioarifendi@gmail.com ${ }^{2}$, elita.selvia@gmail.com \\ *Corresponding Author
}

Received 25 July 2021; revised 14 September 2021; accepted 17 September 2021.

\begin{abstract}
ABSTRAK
Tujuan Penelitian ini adalah untuk mendeskripsikan profil berpikir kritis peserta didik yang memiliki tipe kognitif reflektif dan impulsif. Subjek penelitian ini adalah peserta didik kelas VIII MTs Muhammadiyah 1 Malang. Untuk mendapatkan kelompok gaya kognitif dilakukan Matching Familiar Figures Test (MFFT), kemudian pada masing-masing kelompok dipilih 2 subjek dengan memperhatikan kemampuan komunikasi peserta didik saat mengeluarkan gagasan secara lisan maupun tertulis sesuai hasil wawancara dengan guru matematika. Keempat subjek diberikan soal pemecahan masalah untuk mengetahui profil masing- masing gaya kognitif. Hasil yang diperoleh menunjukkan bahwa peserta didik reflektif mampu memahami masalah, setiap keputusan disertai dengan alasan yang relevan, penarikan kesimpulan tepat, mampu menjelaskan kesimpulan yang dibuat dengan baik serta tidak melakukan overview. Sedangkan untuk peserta didik dengan gaya kognitif impulsif mampu memahami masalah, beberapa alasan yang dikemukakan tidak relevan sehingga penarikan kesimpulan yang dilakukan kurang tepat, dan melakukan overview pada soal yang dirasa mudah. Persamaan peserta didik reflektif dan impulsif terletak pada focus sedangkan perbedaannya terletak pada reason, inference, situation, clarity, dan overview.
\end{abstract}

Kata kunci: berpikir kritis, gaya kognitif, pemecahan masalah.

\begin{abstract}
The purpose of this study is to describe the critical thinking profile of students who have reflective and impulsive cognitive types. The subjects of this study were students of class VIII MTs Muhammadiyah 1 Malang. To get a cognitive style group, a Matching Familiar Figures Test (MFFT) was carried out, then in each group, 2 subjects were selected by taking into account the communication skills of students when expressing ideas orally or in writing according to the results of interviews with mathematics teachers. The four subjects were given problem-solving
\end{abstract}


questions. to find out the profile of each cognitive style. The results obtained indicate that reflective students can understand the problem, each decision is accompanied by relevant reasons, draws the right conclusions, can explain well-made conclusions, and does not do an overview. Impulsive cognitive style can understand the problem, some of the reasons put forward are irrelevant so that the conclusions made are inaccurate, and carry out an overview of the questions that are considered easy. The similarities between reflective and impulsive students lie in focus, while the difference lies in reason, inference, situation, clarity, and overview.

Keywords: critical thinking, cognitive, problem solving

\section{PENDAHULUAN}

Menurut National Council of Teaching of Teacher Mathematics (NCTM), salah satu standar proses pada pembelajaran matematika adalah kemampuan dalam pemecahan masalah, atau yang biasa dikenal dengan problem solving (NCTM, 2000). Pemecahan masalah merupakan hal yang sangat penting dalam pembelajaran matematika (Irianti et al., 2016). Pemecahan masalah merupakan proses mental tingkat tinggi dan memerlukan proses berpikir yang lebih kompleks karena merupakan inti dari matematika, memerlukan kemampuan berpikir kritis yang juga merupakan hal yang penting untuk peserta didik (Haryani, 2011) (Irianti, 2020) (Wijaya \& Irianti, 2021). Ada enam unsur dasar yang perlu dipertimbangkan dalam berpikir kritis menurut Ennis, yaitu focus, reason, inference, situation, clarity, dan overview (Cahyono, 2017).

Terdapat hubungan yang sangat berkaitan erat antara berpikir kritis dengan proses problem solving atau pemecahan masalah. Kemampuan berpikir kritis sangat dibutuhkan dalam memecahkan masalah untuk mencari berbagai alternatif penyelesaian. Sebaliknya, pemecahan masalah dapat digunakan untuk memicu berkembangnya kemampuan berpikir kritis peserta didik (Cahyono, 2016). Apalagi hubungan antara pemecahan masalah dan berpikir kritis didukung penelitian yang dilakukan oleh Sulianto dkk yang menyimpulkan bahwa adanya hubungan yang signifikan antara kemampuan berpikir kritis dan kemampuan memecahkan masalah (Sulianto et al., 2018).

Sayangnya, pentingnya kemampuan pemecahan masalah ini bertolak belakang dengan kondisi yang dialami oleh peserta didik di Indonesia. Indonesia merupakan salah satu negara yang menjadi objek Trend in International 
Mathematics and Science Study (TIMSS) sejak 2003 ini, masih menempati posisi yang rendah (Hadi \& Novaliyosi, 2019). TIMSS yang merupakan studi komparatif internasional yang komprehensif dalam matematika dan sains sejak tahun 1995 ini dilakukan tiap empat tahun sekali (Thomson et al., 2017). Berdasarkan hasil TIMSS yang dilakukan di tahun 2015, kemampuan peserta didik Indonesia dalam matematika berada di urutan 44 dari 49 negara peserta (Prastyo, 2020). Tidak jauh berbeda dengan TIMSS, Programme for International Students Assesment (PISA) yang telah dilakukan di tahun 2018 juga memposisikan Indonesia di urutan 73 dari 79 negara partisipan (Hewi \& Shaleh, 2020). Mendukung hasil TIMMS dan PISA, observasi yang dilakukan peneliti di kelas VIII MTs Muhammadiyah 1 Malang menunjukkan rendahnya kemampuan pemecahan masalah sebagian besar peserta didik. Mayoritas peserta didik tidak mampu menyelesaikan masalah non rutin.

Dari hasil survey PISA dan TIMMS serta observasi yang dilakukan peneliti, memberikan gambaran adanya masalah dalam pembelajaran matematika. Rendahnya kemampuan pemecahan masalah peserta didik Indonesia akan berdampak pada kemampuan berpikir kritis yang menyebabkan tujuan pembelajaran matematika tentang kemampuan berpikir kritis belum tercapai. Namun jika dilakukan pembinaan secara tepat kemampuan berpikir kritis peserta didik dapat ditingkatkan, hal ini dibuktikan dari hasil International Mathematical Olympiad (IMO) pada tahun 2019 Indonesia berada di peringkat 19 dari 101 negara yang berpartisipasi (Iryanti, 2015). Dari hasil tersebut dapat dilihat bahwa peserta didik yang mendapatkan pembinaan tepat mampu bersaing dengan peserta didik dari negara lain. Sebelum dilakukan pembinaan lebih lanjut dan untuk mengatasi kelemahan kemampuan berpikir kritis peserta didik, seorang guru perlu mengetahui profil berpikir kritis peserta didik. Dengan mengetahui profil berpikir kritis, diharapkan guru dapat memperoleh gambaran tentang keadaan peserta didik dalam memecahkan masalah sehingga guru dapat menentukan cara pembelajaran yang sesuai.

Lebih lanjut dari hasil observasi ditemukan pula bahwa aktivitas pemecahan masalah peserta didik dipengaruhi oleh beberapa faktor, salah satu faktor yang berpengaruh adalah gaya kognitif. Dalam merencanakan suatu 
pembelajaran, akan lebih baik jika guru dapat memahami gaya kognitif peserta didiknya. Dengan mengetahui gaya kognitif peserta didik, guru dapat merancang dan memodifikasi materi, tujuan, dan metode pembelajaran yang disesuaikan dengan gaya kognitif peserta didik. Hal ini dikarenakan gaya kognitif mempengaruhi kecepatan dan kecermatan peserta didik dalam menyelesaikan masalah sehingga perbedaan itu juga akan memicu perbedaan berpikir kritis mereka (Fajari et al., 2013). Selanjutnya, beberapa peneliti menjelaskan bahwa kemampuan peserta didik dalam memecahkan masalah dapat berbeda-beda dikarenakan gaya kognitif cukup banyak berpengaruh dalam pemecahan masalah matematika peserta didik (Lusiana, 2017) (Murtafiah \& Amin, 2018) (Reno et al., 2017) (Rosyana \& Rosyidi, 2018). Berdasarkan hal tersebut, dengan mengetahui gaya kognitif peserta didiknya menjadi hal yang penting untuk dilakukan oleh seorang guru.

Gaya kognitif adalah bentuk dari aktivitas kognitif yang bersifat stabil sepanjang waktu, namun bukan berarti tidak dapat diubah (Wulan, 2019). Salah satu gaya kognitif yang dimiliki peserta didik adalah reflektif dan impulsif. Kagan berpendapat bahwa anak tergolong impulsif jika anak tersebut memiliki karakteristik cepat dalam menjawab masalah tetapi kurang cermat dan hasil jawaban cenderung salah. Sedangkan anak tergolong bergaya kognitif reflektif memiliki karakteristik lambat dalam menjawab masalah tetapi cermat atau teliti dan jawaban cenderung benar. Berdasarkan fakta-fakta yang ditemukan peneliti selama melakukan observasi dan merujuk pada definisi yang dikemukakan oleh Kagan (Kagan, 1966), peneliti menyimpulkan bahwa salah satu gaya kognitif yang berpengaruh pada peserta didik saat penyelesaian masalah adalah gaya kognitif reflektif dan impulsif.

Peneliti menggunakan materi Sistem Persamaan Linear Dua Variabel (SPLDV) untuk mengetahui profil berpikir kritis peserta didik dalam memecahkan masalah. Hal ini dikarenakan materi SPLDV menggabungkan beberapa konsep dasar matematika yang dapat dijadikan sebagai stimulus dalam mengeluarkan proses berpikir kritis peserta didik (Mubarik, 2013). Berdasarkan uraian tersebut, tujuan penelitian ini adalah untuk mendeskripsikan profil berpikir kritis peserta didik ditinjau dari gaya kognitif dalam memecahkan masalah matematika. 


\section{METODE PENELITIAN}

Penelitian ini menggunakan pendekatan kualitatif dengan jenis deskriptif eksploratif. Adapun subjek dalam penelitian ini adalah peserta didik kelas VIII MTs Muhammadiyah 1 Malang. Subjek penelitian ini dipilih dengan memberikan tes MFFT (Matching Familiar Figures Test). Tes MFFT merupakan alat instrumen yang digunakan untuk menilai gaya kognitif impulsif-reflektif (Herianto, 2020) (Kagan, 1966). MFFT diberikan kepada peserta didik kelas VIII.

Berdasarkan hasil tes, diambil 4 peserta didik yang terdiri dari 2 peserta didik berkarakteristik impulsif dan 2 peserta didik berkarakteristik reflektif. Selain itu, juga diperhatikan kemampuan komunikasi peserta didik saat mengeluarkan gagasan baik secara lisan maupun tertulis. Setelah melakukan tes MFFT, peneliti memberikan tes pemecahan masalah kepada peserta didik mengenai SPLDV. Peneliti juga melakukan wawancara dengan keempat subjek yang bertujuan untuk mendapatkan informasi baru yang tidak diperoleh saat tes pemecahan masalah.

\section{HASIL PENELITIAN DAN PEMBAHASAN}

\section{A. Profil Berpikir Kritis Peserta Didik Berdasarkan Gaya Kognitif Reflektif}

Berikut merupakan jawaban peserta didik reflektif yang menunjukkan mampu memahami permasalahan.

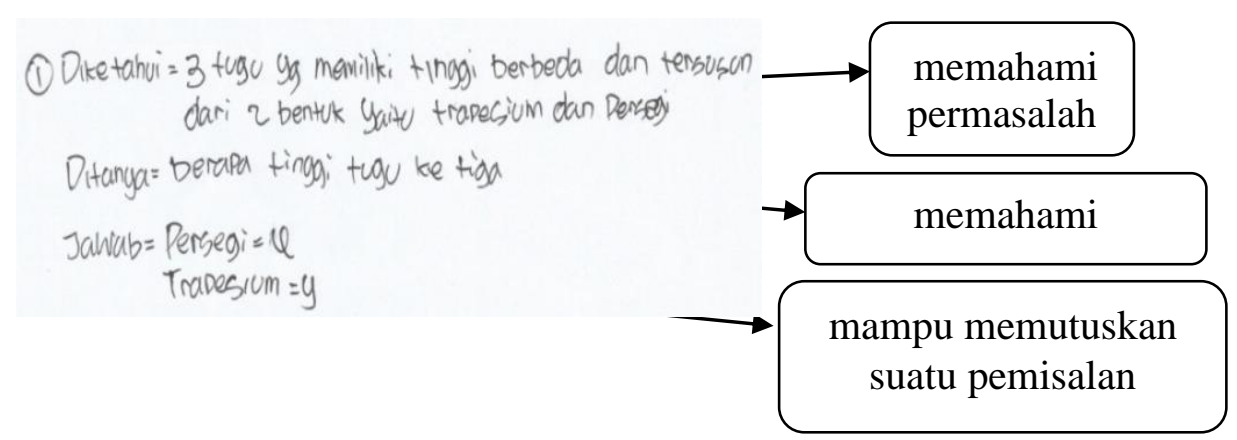

Gambar 1. Jawaban Peserta Didik Kriteria Focus

Berdasarkan Gambar 1, peserta didik memahami bahwa informasi yang tersedia mengenai tinggi kedua tugu yang berbeda dengan tugu tersebut tersusun dari bentuk trapesium dan persegi. Peserta didik memutuskan membuat pemisalan yaitu persegi sebagai $x$ dan trapesium sebagai $y$. Peserta didik reflektif memahami permasalahan yang diberikan dengan cara membaca permasalahan dengan cermat. 
Sesuai dengan yang diungkapkan oleh Santrock bahwa peserta didik reflektif membaca dengan memahami dan menginterpretasikan teks (Santrock, 2009). Peserta didik mampu memutuskan untuk membuat pemisalan menggunakan variabel $x$ dan variabel $y$. Hal ini sesuai dengan pengertian berpikir kritis yang diungkapkan oleh Kalelioglu \& Gulbahar bahwa kegiatan berpikir kritis yang dilakukan oleh peserta didik merupakan suatu cara berpikir dan suatu kumpulan keterampilan terkait dengan pengambilan keputusan (Kalelioğlu \& Gülbahar, 2013).

Peserta didik mampu memberikan alasan dari SPLDV yang dibuatnya berdasarkan keterangan atau fakta yang terdapat pada soal. Philip mengatakan bahwa anak berkarakteristik reflektif memperhatikan berbagai alternatif sebelum merespon yang menyebabkan respon yang diberikan selalu mendekati benar (Firestone \& Douglas, 1977). Peserta didik reflektif mampu memberikan penjelasan yang tepat dari langkah yang dilakukan selama menyelesaiakan sistem persamaan linear dua variabel. Hal ini dapat dilihat dari jawaban peserta didik pada Gambar 2.

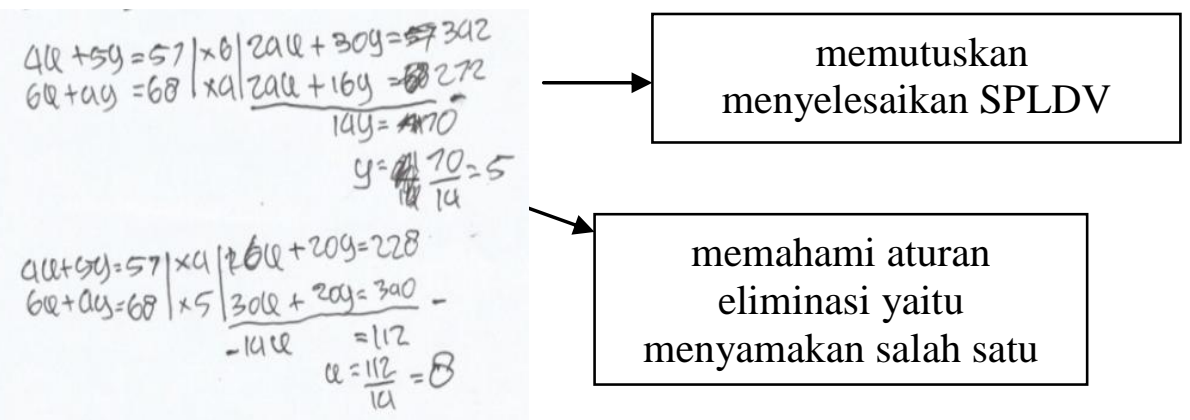

Gambar 2. Jawaban Peserta Didik Kriteria Inference

Jawaban peserta didik pada soal ini menunjukkan bahwa ia membuat kesimpulan dengan tepat yaitu menyelesaikan sistem persamaan yang telah dibuat dengan cara eliminasi. Peserta didik memahami aturan dari eliminasi yaitu menyamakan variabel sehingga dia mengalikan persamaan (1) dan persamaan (2) dengan bilangan tertentu. Pada saaat wawancara peserta didik reflektif lama mempertimbangkan jawaban yang akan diberikan. Gambar 3 adalah jawaban peserta didik yang menunjukkan peserta didik reflektif mampu membuat kesimpulan dengan tepat. 

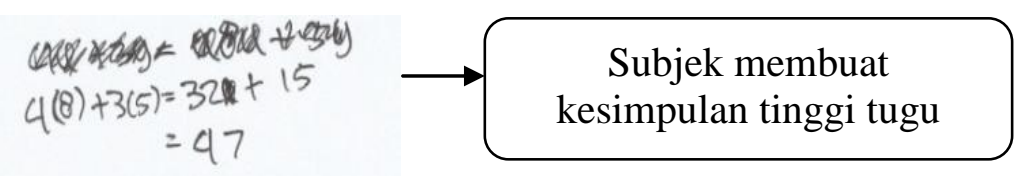

Gambar 3. Jawaban Peserta Didik Mengenai Kesimpulan Akhir

Peserta didik reflektif mampu memberikan penjelasan lebih lanjut dari kesimpulan akhir pada semua jawabannya. Peserta didik reflektif tidak melakukan pengecekan kembali terhadap jawabannya atau tidak melakukan tahap overview dikarenakan meyakini bahwa jawabannya telah benar. Berdasarkan data profil berpikir kritis peserta didik reflektif dapat dibuat alur berpikir kritis peserta didik seperti Gambar 4.

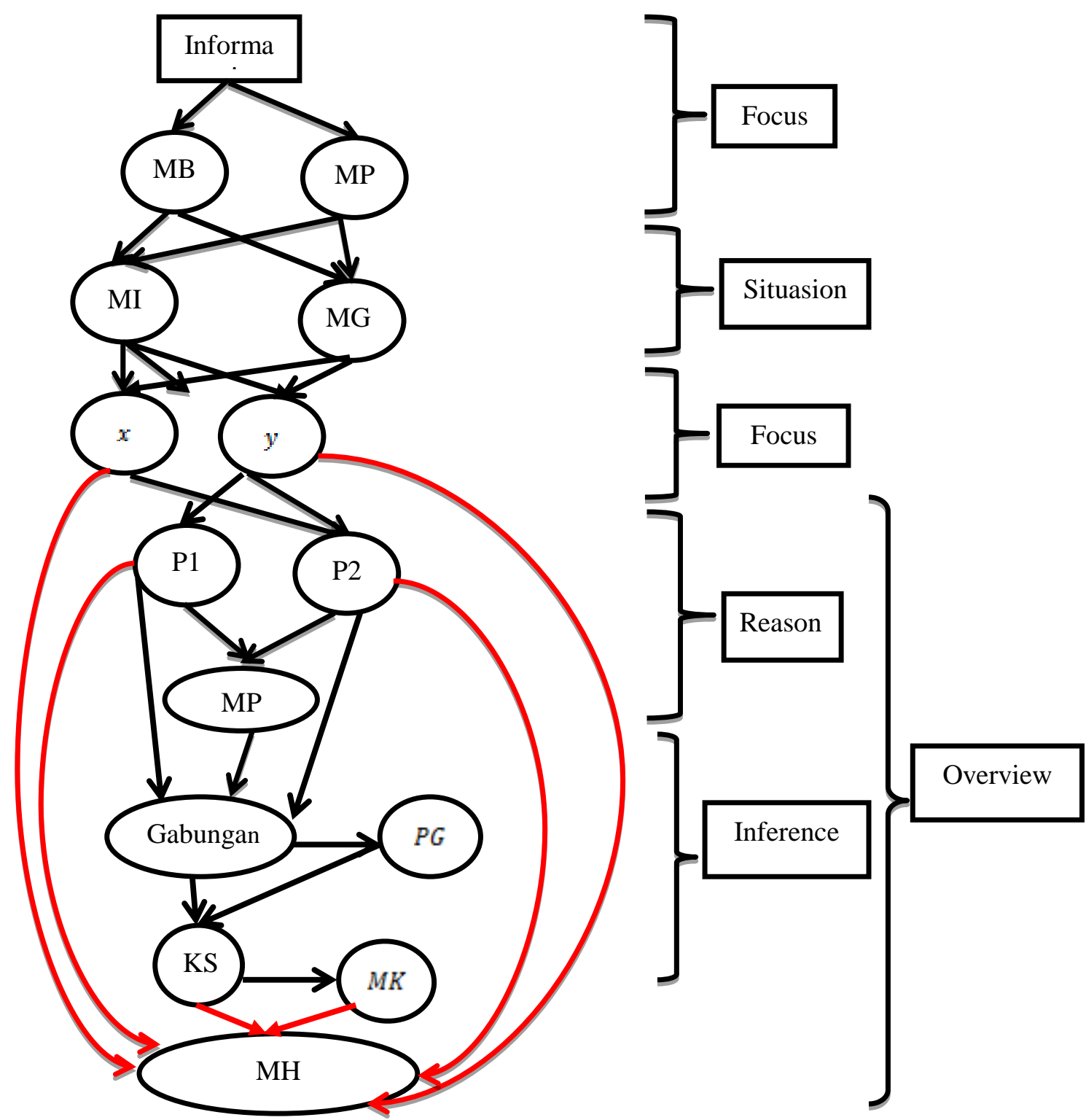

Gambar 4. Alur Berpikir Kritis Peserta Didik Reflektif 
Keterangan:

$\begin{aligned} \text { MB } & : \text { membaca masalah, } & \text { MP } & : \text { menjelaskan persamaan, } \\ \text { MP } & : \text { memahami pertanyaan, } & \text { PG } & : \text { penjelasan cara gabungan, } \\ \text { MI } & : \text { menggunakan semua informasi, } & \text { KS } & : \text { membuat kesimpulan, } \\ \text { MG } & : \text { memperhatikan gambar, } & \text { MK } & : \text { menjelaskan kesimpulan, } \\ x & : \text { pemisalan pertama, } & \text { MH } & : \text { memeriksa hasil, } \\ \text { y } & : \text { pemisalan kedua, } & \longrightarrow & : \text { tahap dilakukan, } \\ \text { P1 } & : \text { persamaan satu, } & & : \text { tahap tidak dilakukan, } \\ \text { P2 } & : \text { persamaan dua. } & & \end{aligned}$

\section{B. Profil Berpikir Kritis Peserta Didik Berdasarkan Gaya Kognitif Impulsif}

Peserta didik impulsif memahami permasalahan sistem persamaan linear dua variabel yang diberikan. Adapun hasil jawaban peserta didik ditunjukkan pada Gambar 5.

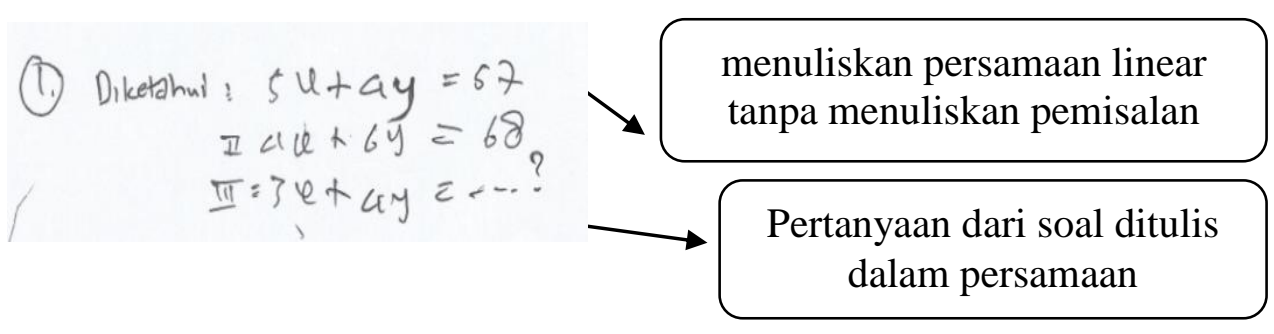

Gambar 5. Jawaban Peserta Didik Impulsif Kriteria Focus

Peserta didik mampu memahami bahwa informasi yang tersedia mengenai tinggi kedua tugu yang berbeda dimana tugu tersebut tersusun dari bentuk trapesium dan persegi. Informasi yang diberikan pada soal dituliskan pada jawabannya menggunakan persamaan linear dua variabel. Untuk tujuan yang ditanyakan dari soal, langsung menulis dalam persamaan tidak dengan kata-kata.

Peserta didik impulsif memberikan penjelasan pada setiap langkah pengambilan keputusan namun dalam memberikan alasan, peserta didik cenderung singkat dan cepat serta ada beberapa alasan yang tidak relevan. Berdasarkan jawaban dapat dituunjukkan bahwa peserta didik impulsif belum mampu membuat kesimpulan dengan tepat sesuai dengan tujuan soal. 


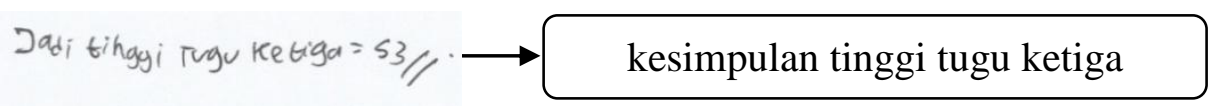

Gambar 6. Jawaban Peserta Didik Reflektif Kriteria Inference

Berdasarkan Gambar 6, nampak bahwa peserta didik tidak membuat kesimpulan akhir dengan tepat sesuai dengan tujuan dari soal. Kesimpulan akhir yang dibuat adalah "Tinggi tugu ketiga adalah $53 \mathrm{~m}$ ”. Nilai 53 merupakan nilai $y$, sehingga menyimpulkan bahwa tinggi tugu ketiga adalah $y$.

Peserta didik impulsif kurang mampu menggunakan beberapa informasi penting dari soal. Peserta didik impulsif tidak mampu memberikan penjelasan lebih lanjut. Peserta didik impulsif melakukan pengecekan hanya pada soal yang dirasa mudah, sedangkan pada soal yang dirasakan sulit peserta didik tidak memeriksa kembali jawabannya. Adapun alur profil berpikir kritis peserta didik dalam memecahkan masalah dapat dilihat pada Gambar 7.
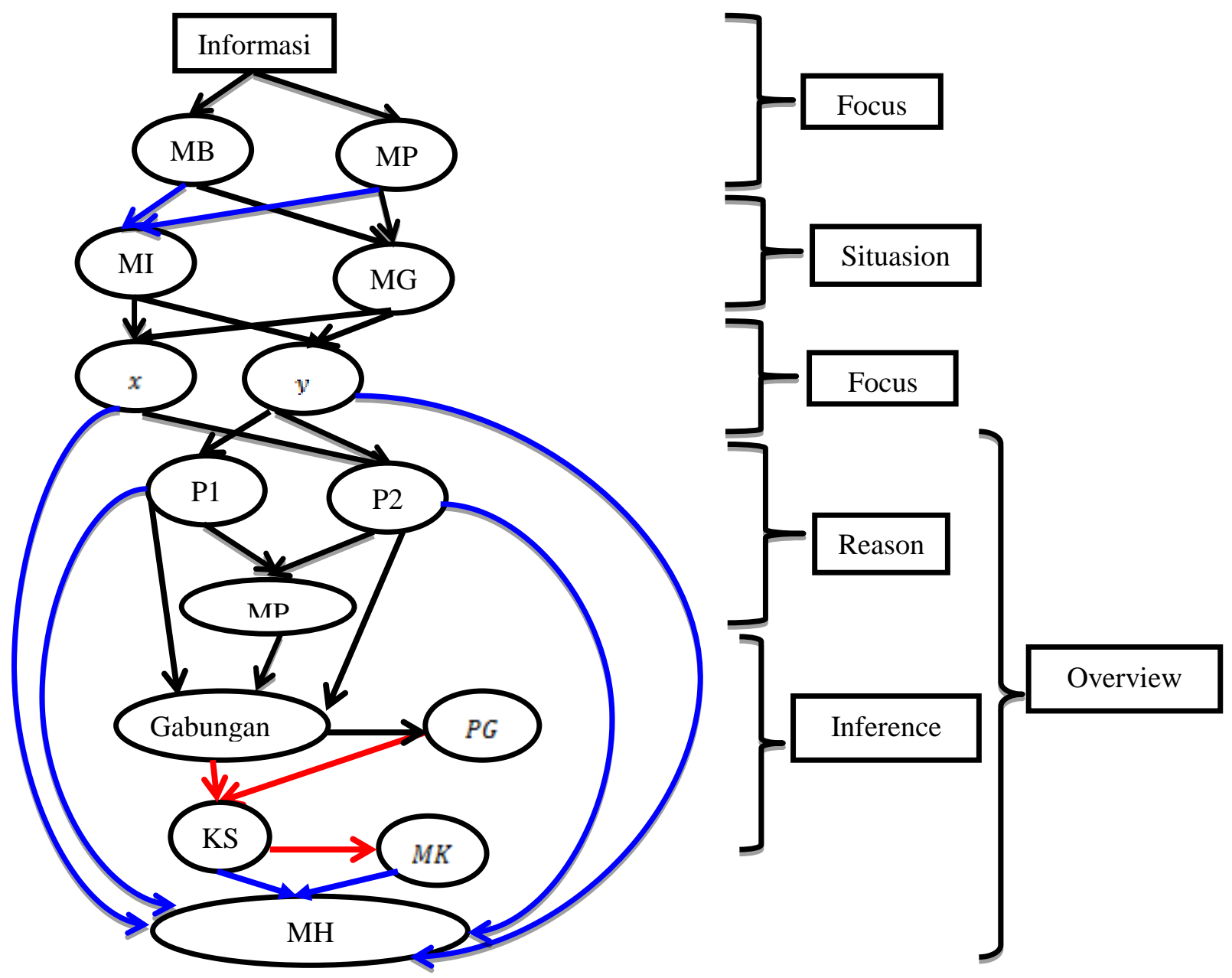

Gambar 7. Alur Berpikir Kritis Peserta Didik Impulsif 
Keterangan:

$\begin{array}{llll}\text { MB } & : \text { membaca masalah, } & \text { MP } & : \text { menjelaskan persamaan, } \\ \text { MP } & : \text { memahami pertanyaan, } & \text { PG } & : \text { penjelasan cara gabungan, } \\ \text { MI } & : \text { menggunakan semua informasi, } & \text { KS } & : \text { membuat kesimpulan, } \\ \text { MG } & : \text { memperhatikan gambar, } & \text { MK } & : \text { menjelaskan kesimpulan, } \\ x & : \text { pemisalan pertama, } & \text { MH } & : \text { memeriksa hasil, } \\ y & : \text { pemisalan kedua, } & \longrightarrow & : \text { tahap dilakukan, } \\ \text { P1 } & : \text { persamaan satu, } & & : \text { tahap tidak dilakukan, } \\ \text { P2 } & : \text { persamaan dua. } & \longrightarrow & : \text { ada bagian tidak dilakukan }\end{array}$

\section{Persamaan Profil Berpikir Kritis Peserta Didik Reflektif dan Impulsif}

Peserta didik reflektif dan impulsif mampu memfokuskan permasalahan yang tersedia untuk membuat sebuah keputusan tentang yang diyakini serta mampu memahami tujuan dari soal yang diberikan. Hal ini terbukti dari peserta didik mampu membuat pemisalan secara tepat untuk membentuk sistem persamaan linear dua variabel. Langkah awal adalah membuat pemisalan menandakan peserta didik mampu memahami tujuan dari soal. Hal ini juga dibuktikan dari hasil wawancara peserta didik yang mampu menjawab dengan benar maksud atau tujuan dari masing-masing soal.

\section{Perbedaan Profil Berpikir Kritis Peserta Didik Reflektif dan Impulsif}

Perbedaan profil berpikir kritis secara jelas dari peserta didik reflektif dan impulsif dapat dilihat pada Tabel 1 .

Tabel 1. Perbedaan Profil Berpikir Kritis Peserta Didik Reflektif dan Impulsif

\begin{tabular}{llrlll}
\hline Kriteria & \multicolumn{2}{c}{ Reflektif } & & \multicolumn{2}{c}{ Impulsif } \\
\hline Reason & Kemampuan & & dalam & Memberikan alasan cenderung \\
& mengemukakan & alasan & sesuai & cepat dan singkat dalam setiap \\
& dengan fakta & pada & setiap & langkah membuat keputusan, serta \\
& langkah & dalam & membuat & ada beberapa alasan yang kurang \\
& keputusan maupun kesimpulan. & relevan. & \\
Inference & Kemampuan & dalam & Belum & mampu \\
& menyimpulkan & sesuatu & dan & kesimpulan yang tepat.
\end{tabular}




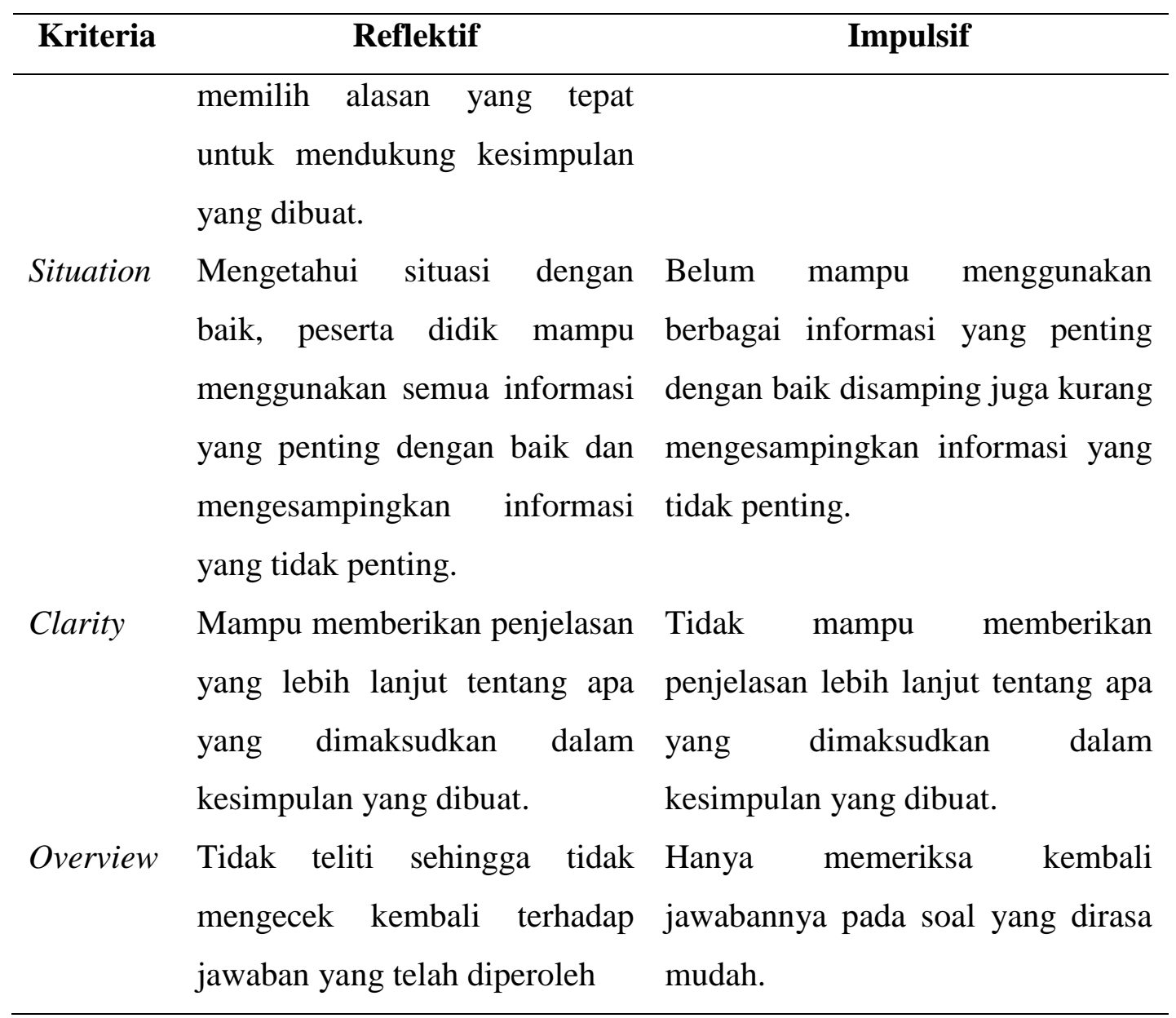

\section{SIMPULAN}

Profil berpikir kritis peserta didik reflektif antara lain (1) pada kriteria focus dapat memahami permasalahan dan pertanyaan terkait sistem persamaan linear dua variabel, (2) mampu dalam memberikan alasan yang tepat, (3) membuat kesimpulan sesuai dengan maksud soal, (4) mampu memahami situasi dengan baik di sekitarnya, (5) mampu menjelaskan kembali dengan baik mengenai kesimpulan yang sudah dibuat, (6) sedangkan untuk overview peserta didik tidak melakukan pengecekan kembali. Profil berpikir kritis peserta didik impulsif antara lain (1) pada kriteria focus peserta didik dapat memahami masalah yang berkaitan dengan materi sistem persamaan linear dua variabel, (2) memberikan alasan (reason) singkat dan ada beberapa alasan yang tidak sesuai dengan pertanyaan, (3) kesimpulan yang dibuat (inference) masih terdapat ketidaksesuaian dengan tujuan soal, (4) kurang baik dalam mengetahui situasi, (5) tidak mampu mengemukakan alasan dari kesimpulan yang dibuatnya, dan (6) untuk kriteria overview peserta 
didik mengecek kembali hanya pada soal yang dirasa mudah. Persamaan antara profil berpikir kritis peserta didik reflektif dan impulsif terlihat dari kritera focus. Perbedaan profil berpikir kritis terlihat pada kriteria reason, inference, situation, clarity, dan overview.

\section{UCAPAN TERIMA KASIH}

Terima kasih disampaikan kepada kepala sekolah dan guru MTs Muhammadiyah 1 Malang yang telah bersedia bekerjasama dalam penelitian ini dari awal hingga akhir. Terima kasih juga kepada jajaran pimpinan dan kolega peneliti di Universitas Tribhuwana Tunggadewi yang telah mendukung hingga penelitian ini dapat diselesaikan dengan baik.

\section{DAFTAR PUSTAKA}

Cahyono, B. (2016). Korelasi pemecahan masalah dan indikator berfikir kritis. Phenomenon: Jurnal Pendidikan MIPA, 5(1), 15-24. https://doi.org/10.21580/phen.2015.5.1.87

Cahyono, B. (2017). Analisis ketrampilan berfikir kritis dalam memecahkan masalah ditinjau perbedaan gender. Aksioma: Jurnal Matematika dan Pendidikan Matematika, 8(1), 50-64. https://doi.org/10.26877/aks.v8i1.1510

Firestone, P., \& Douglas, V. I. (1977). The effects of verbal and material rewards and punishers on the performance of impulsive and reflective children. Child study journal, 7(2), 71-78.

Fajari, A. F. N., Kusmayadi, T. A., \& Iswahyudi, G. (2013). Profil poses berpikir kritis siswa dalam pemecahan masalah matematika kontekstual ditinjau dari gaya kognitif field dependent-independent dan gender Setiap individu adalah seorang pemikir kritis. Jurnal Pembelajaran Matematika, 1(6), 639-648.

Hadi, S., \& Novaliyosi. (2019). TIMSS Indonesia (trends in international mathematics and science study). In Prosiding Seminar Nasional \& Call For Papers Program Studi Magister Pendidikan Matematika Universitas Siliwangi (pp. 562-569).

Haryani, D. (2011). Pembelajaran matematika dengan pemecahan masalah untuk menumbuhkembangkan kemampuan berpikir kritis siswa. In Prosiding Seminar Nasional Penelitian, Pendidikan dan Penerapan MIPA, Fakultas MIPA, Universitas Negeri Yogyakarta (Vol. 14, No. 1, pp. 20-29).

Herianto. (2020). Matching familiar figures tes (MFFT): intrumen tes untuk mengukur gaya kognitif siswa reflektif dan impulsif. Turkish Journal of Chemistry, 53(2), 391-401. https://doi.org/10.31219/osf.io/34ut8

Hewi, L., \& Shaleh, M. (2020). Refleksi hasil PISA (the programme for international student assesment): upaya perbaikan bertumpu pada pendidikan anak usia dini. Jurnal Golden Age, 4(1), 30-41. 
https://doi.org/10.29408/jga.v4i01.2018

Irianti, N. P. (2020). Analisis kemampuan penalaran siswa dalam memecahkan masalah matematika berdasarkan langkah-langkah polya. MUST: Journal of Mathematics Education, Science and Technology, 5(1), 80-94. https://doi.org/10.30651/must.v5i1.3622

Irianti, N. P., Subanji, S., \& Chandra, T. D. (2016). Proses berpikir siswa quitter dalam menyelesaikan masalah SPLDV berdasarkan langkah-langkah polya. JMPM: Jurnal Matematika dan Pendidikan Matematika, 1(2), 133142. https://doi.org/10.26594/jmpm.v1i2.582

Iryanti, P. (2015). Fakta-fakta menarik dari hasil international mathematical olympiad (IMO). Retrieved from PPPPTK Matematika: http://p4tkmatematika.kemdikbud.go.id/artikel/2015/01/15/imo/

Kagan, J. (1966). Reflection-impulsivity: the generality and dynamics of conceptual tempo. Journal of Abnormal Psychology, 71(1), 17-24. https://doi.org/10.1037/h0022886

Kalelioğlu, F., \& Gülbahar, Y. (2013). The effect of instructional techniques on critical thinking and critical thinking dispositions in online discussion. Educational Technology and Society, 17(1), 248-258.

Lusiana, R. (2017). Analisis kesalahan mahasiswa dalam memecahkan masalah pada materi himpunan ditinjau dari gaya kognitif. Jurnal Penelitian dan $\begin{array}{lll}\text { Pembelajaran } \quad \text { Matematika, } & \text { 24-29. }\end{array}$ https://doi.org/10.30870/jppm.v10i1.1290

Mubarik. (2013). Profil pemecahan masalah siswa auditorial kelas X SLTA pada materi sistem persamaan linear dua variabel. Jurnal Elektronik Pendidikan Matematika Tadulako, 1(1), 9-17.

Murtafiah, M., \& Amin, N. (2018). Pengaruh gaya kognitif dan gender terhadap kemampuan pemecahan masalah matematika. JPPM (Jurnal Penelitian dan Pembelajaran Matematika), $11(1) . \quad$ 75-82. https://doi.org/10.30870/jppm.v11i1.2986

NCTM. (2000). Principles and standards for school mathematics. Retrieved from National Council of Teachers of Mathematics: https://www.nctm.org/uploadedFiles/Standards_and_Positions/PSSM_Exe cutiveSummary.pdf

Prastyo, H. (2020). Kemampuan matematika siswa indonesia berdasarkan TIMSS. Jurnal Padegogik, 3(2), 111-117. https://doi.org/10.35974/jpd.v3i2.2367

Reno, P., Geni, L., \& Hidayah, I. (2017). Kemampuan pemecahan masalah siswa pada pembelajaran problem based learning bernuansa etnomatematika ditinjau dari gaya kognitif. Unnes Journal of Mathematics Education Research, 6(1), 11-17.

Rosyana, A., \& Rosyidi, A. H. (2018). Profil pemecahan masalah matematika kontekstual terbuka siswa ditinjau dari gaya kognitif reflektif dan impulsif. MATHEdunesa, 7(2), 299-307.

Santrock, J. W. (2009). Psikologi Pendidikan (edisi tiga, jilid 2). Jakarta: Salemba Humanika.

Sulianto, J., Cintang, N., \& Azizah, M. (2018). Analisis korelasi dan regresi berpikir kritis terhadap siswa SD kota Semarang. In Seminar Nasional Pendidikan 2018 (pp. 237-246).

Thomson, S., Wernert, N., O'grady, E., \& Rodrigues, S. (2017). PISA 2015: 
reporting Australia's results. In ACER: https://www.acer.edu.au

Wijaya, E. M. S., \& Irianti, N. P. (2021). Meningkatkan kemampuan berpikir kritis mahasiswa melalui realistic mathematic education (RME). AKSIOMA: Jurnal Program Studi Pendidikan Matematika, 10(2), 648658. http://dx.doi.org/10.24127/ajpm.v10i2.3103

Wulan, E. R. (2019). Gaya kognitif field-dependent dan field-independent sebagai jendela profil pemecahan masalah polya dari siswa SMP. Journal Focus Action of Research Mathematic (Factor M), 1(2), 123-142. https://doi.org/10.30762/f_m.v1i2.1503 